\title{
TYPOGRAPHY AS A MEDIATOR OF ART, SPACE, MEMORY AND PRESENCE ON TOPONYMY
}

\author{
Miranda-Dos Santo, Tiago José \\ TYPOGRAPHY AS A MEDIATOR OF ART, SPACE, MEMORY AND PRESENCE ON TOPONYMY \\ Revista Legado de Arquitectura y Diseño, vol. 2019, núm. 26, 2019 \\ Universidad Autónoma del Estado de México, México \\ Disponible en: http://www.redalyc.org/articulo.oa?id=477961406007
}

Esta obra está bajo una Licencia Creative Commons Atribución-NoComercial-SinDerivar 4.0 Internacional. 


\title{
TYPOGRAPHY AS A MEDIATOR OF ART, SPACE, MEMORY AND PRESENCE ON TOPONYMY
}

\author{
TIPOGRAFÍA COMO MEDIADOR DE ARTE, \\ ESPACIO, MEMORIA Y PRESENCIA EN TOPONIMIA
}

Tiago José Miranda-Dos Santo tiago.santos@uc.pt

Universidade de Coimbra, Portugal Revista Legado de Arquitectura y Diseño,
vol. 2019, núm. 26, 2019

Universidad Autónoma del Estado de México, México

Recepción: 31 Diciembre 2018 Aprobación: 23 Marzo 2019

Redalyc: http://www.redalyc.org/ articulo.oa?id $=477961406007$

\begin{abstract}
Communication through some media gives meaning to a message, or can express the desire to communicate. Throughout history, typography has been at culture and written communication's service, responding to the languages, cultures and societies' evolution stimuli. Its history should be understood as the study, from the political, philosophical and artistic point-of-view, of the several movements and the history of humanity. Therefore, the proper use of typography demands mastery of its form and use, in favour of its content, leaving space for a rational expression of the human world, built by his knowledge, imagination, wishes and desires. To conclude, the form of typography depends on the language of the text and its medium, referring back to spatial perception and each's surroundings, contributing directly to its memory construction.

Until 1974, Portugal was a very closed country, which prevented a widespread visual homogenisation of the urban. This fact led to the existence of an unusual typographic heritage, yet it is not connoted a specific typographic style. According to Balius (2013), further development on the reflection of the social impact of typography is needed. This article proposes to examine current signposts typography present on the city of Coimbra, Portugal, identifying and analysing shapes, types and typographic families of dominant and distinct letters, referring to the space analysis and its history, compared to the place and the history of typography. This analysis enables history as an active object, allowing the transmission of typographic legate beyond the scope of the design.
\end{abstract}

Keywords: space, memory, typography, Coimbra, Portugal.

Resumen: La comunicación a través de algunos medios da sentido a un mensaje, o puede expresar el deseo de comunicarse. A lo largo de la historia, la tipografia ha estado al servicio de la cultura y la comunicación escrita, respondiendo a los estímulos evolutivos de las lenguas, las culturas y las sociedades. Su historia debe entenderse como el estudio, desde el punto de vista politico, filosófico y artistico, de los diversos movimientos y la historia de la humanidad. Por lo tanto, el uso adecuado de la tipografía exige el dominio de su forma y uso, a favor de su contenido, dejando espacio para la expresión racional del mundo humano, construido por su conocimiento, imaginación, deseos y deseos. Para concluir, la forma de la tipografia depende del lenguaje del texto y su medio, refiriéndose a la percepción espacial y al entorno de cada individuo, contribuyendo directamente a la construcción de su memoria.

Hasta 1974, Portugal era un pais muy cerrado, lo que impedia una homogeneización visual generalizada de lo urbano. Este hecho llevó a la existencia de un patrimonio tipográfico inusual, pero no está connotado con un estilo tipográfico especifico. Según Balius (2013), se necesita un mayor desarrollo sobre la reflexión del impacto social de la tipografia. Este articulo propone examinar las tipografias actuales de la ciudad de Coimbra, Portugal, identificando y analizando formas, tipos y familias tipográficas de letras dominantes y distintas, en referencia al análisis del espacio y su historia, en comparación con el lugar y la historia de la tipografia. Este análisis habilita la historia como un objeto activo, permitiendo la transmisión de legados tipográficos más allá del alcance del diseño.

Palabras clave: espacio, memoria, tipografía, Coimbra, Portugal. 


\section{INTRODUCTION}

By living in a community, humans soon felt the need to communicate. The history of human evolution is also the evolution of their forms of communication. Oral or verbal communication allows humans to communicate with each other, yet, this kind of communication is shortlived, as its perpetuation depends on the constant repetition. When the context of communication or medium changes, the receptor has a message which is delivered differently. This can change the way it is perceived (Berger, 1995) due to the social and cultural environment and also due to the education and life experience of individuals (Mitchel, 2005).

Oral or verbal communication

ALLOWS HUMMNS TOCOMMUNNCATE WITH EMCH OTHER, YET.

THIS KIND OF COMMUNICATION IS SHORTLVED,

as is perpetzation depends on the constant repetition.

Due to the need for creating lasting communication, humans had to research and develop their communication skills and use tangible objects to complement verbal communication. Social themes, like hunting or religion, have been represented by primitive humans as figures carved in rocks. These representations were the first forms of written communication perpetuating everyday experiences and habits of ancient humans, which allowed the intergenerational communication. Written communication has evolved from rock figures to cuneiform scripts, as a representation of sound, until the advent of the first alphabets. The development of written communication occurred, in different ways all over the world, resulting in different word representations in each place. The oldest European typographic forms, according to Bringhurst (2004), are the Greek stone inscriptions, as well as the quadratta inscriptions, which can be found on the Trajan's columns in Rome.

Since the early days, sharing knowledge has been very important to human development. The use of different materials, from cave walls to papyrus, not forgetting stone inscriptions, has been fundamental to the perpetuity of the knowledge of each historic period. With the increasing demand for manuscripts, it was necessary to maximise the use of written support (Brighurst, 2004) and diminish their execution time. Simpler and quicker drawings began to be used, diminishing the communication time. We should notice that until the 15th century, typography was essentially a manual work, without any technology allowing its automation or diminishing its execution time. It was in that century that Joannes Gutenberg imported, and developed, printing technologies to Europe, together with the use of paper (Meggs \& Purvis 2006). Guttenberg's work revolutionized the production of books, not only by its speed, but also by its printing quality, without regarding the traditional book decoration produced until then. Soon, book production was massified throughout several cultural centres, stimulating the production of books in local languages, as opposed to 
Latin. Typography achieved a spatial dimension (Brighurst, 2004), with cultural connotations and proper vocabulary (Reminghton, 2012). This development is deeply related to the aesthetics of each language region (Reminghton, 2012), its evolution, and it demarked how a text is viewed, as well as the space required to its legibility (Balius, 2013).

\section{TOPONYMY, A CONTAINER OF MEMORY OF SPACE}

Toponymy is the science which studies the names of places, as well as their origins, meanings and habits keeping up with urban and population development. It follows the changes in the life of communities, their experiences, traditions and their cultural and social-economic activities (Nunes, 2008). Toponymic plates, or signs, are wayfinding systems, which exploit a toponym (Houaiss \& Villar, 2001) to indicate, suggest or recognize space (Uebele, 2007). Through observation mindful to each place's toponym, it is possible to learn about its history on several layers. Toponym plates are an important instrument which takes advantage of typography. It enables an individual, on a given location, to identify and recognize the surrounding space and locate himself in the world while mentally reconstructing space (Umbellino, 2013) and from then on, to find a path to a certain place (Arthur \& Passini, 1992).

Toponym started to be used by every local population which, without any other reasons to name each place, named them according to the dayto-day actions (D'Encarnação, 2010). This is visible in major cities, until the second half of the 19th century, wherewith urban development, as well as the advent of parliamentarism and a bigger civic participation, names were given to streets, squares, parks or gardens (D'Encarnação, 2010), allowing the recognition of their identities and geographic references, easing mobility in space (Barreto, 2005).

In Évora, the capital of Alentejo, Portugal, its toponym was created, as a matter of fact, in the second half of the 19th century, by a local politician. It was immediately recognized as a public utility project which still endures today (Afonso, 2014). Évora's toponym signage has acquired a consistent aesthetic, to this day exploiting the traditional Portuguese ceramic tiles techniques with particular attention regarding typography, legibility and reading ability (Afonso, 2014). Évora's letterings are characterized by their elliptical shape and the use of a didone typeface, which are considered an artistic, social and cultural asset important to local heritage (Afonso, 2014). They are also catalogued as components - of the public service, necessary for the convenience in the working life of the Évora's society (Afonso, 2014). 


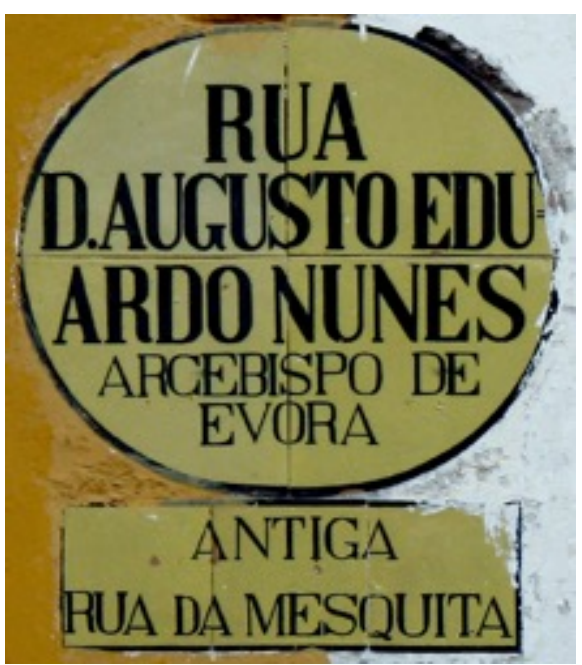

Figure 1. Évora's Toponomy Sign. Source: $\odot$ A Afonso, (2014).

Toponomy signage can, if presented grouped within a graphic system, be identified, and easily recognized, as a reliable signalling system (Barreto, 2005). The expression of toponomy, through consistent use of typography and other decorative elements, can confer a visual identity, or personality, to a given zone, serving as a visual reference to the observer (Félix, 2013; Baines \& Dixon, 2003). Toponomy can also be a proof and a demonstration of the evolution of every language, as it happens in Évora, where each lettering shows the places' nomenclature in old spelling, resisting and adapting to constant mutations of the language and orthographic agreements (Afonso, 2014). According to Afonso (2014), "Raymundo", "Collegio" and "Cosinha" are the words from the past that belong to the Portuguese identity, and which should not be corrected or modified, despite not being used nowadays. Thus, the presence of the primitive toponym signage, or similar to this, can present itself as an intention of preserving the expressivity and artistic identity of a region (Baines \& Dixon, 2003). This identity was consolidated, as years went by, in the local population's memory, its form and its function (Afonso, 2014; Umbelino, 2013). From the other point of view, toponym can bring us new perspectives on ideologies, local, and national, historical, cultural, religious and economic options made or developed through time (D’Encarnação, 2010).

In Portuguese toponymy, it is common to find references to the old places' names, along with the actual name. On Évoras toponym, as well as Beja (another city in the Alentejo region), the same information hierarchy has been used. The old name is placed on the second group of tiles, below the main circular group of the ceramic tiles. 


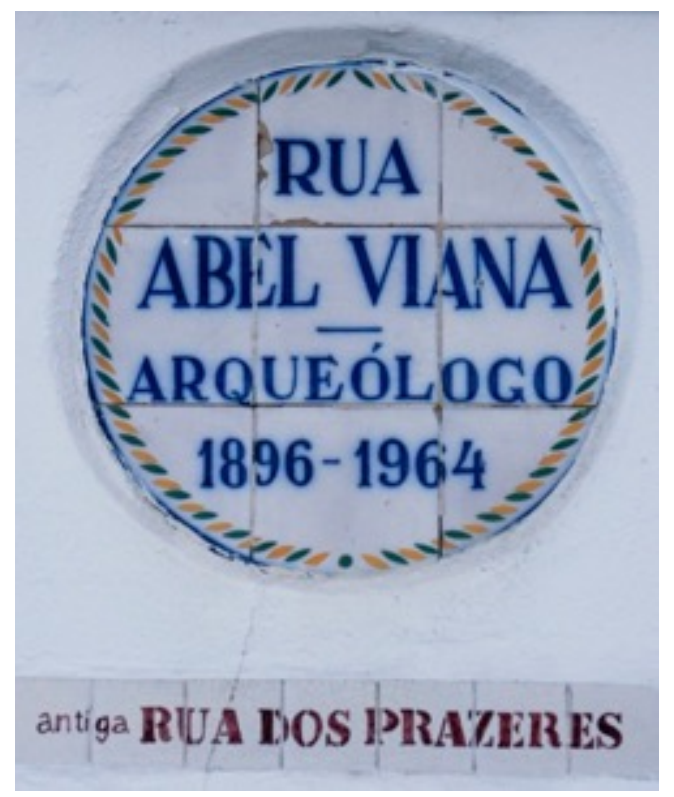

Figure 2. Beja Toponym Signage.

Source: () Santos, (2013).

According to the Évora's City Documentation Centre, these secondary toponymy panels appeared, to fulfil the openly expressed population's desire to see the old street names (Afonso, 2014). Those two tile panels (figure 1,2) are examples of a proper information hierarchy, which takes advantage of the typography's weight, in Évora, and the colour, shape and contrast, in Beja, highlighting the former toponymy instead of the actual ones.

Classic Portuguese toponymy signage is mostly made of stone, marble or granite, or even ceramic tiles (Félix, 2013), besides those materials, zinc is also used. Nowadays a predominance of ceramic tiles is seen as a toponomy communication asset. Some municipalities have adopted newer materials like polymers, yet they are less durable than the classic ones (figure 4), they also disrupt urban landscape's identity, mostly in areas famous for the ceramics production (Félix, 2013). Signage on enamelled plate or PVC decorated with trimmed vinyl are the least resistant to weather and environment conditions (Félix, 2013). The popularity of ceramic tiles on Portuguese toponym signage in opposition to other materials becomes evident, as they are cheap to produce and can last for very long periods (Félix, 2013). Ceramics is one of the few materials, which design and creativity applied on its surface is as important, as the material production (Lefteri, 2003). Additionally, there is an emotional bond to this material, which is present everywhere and has a visual and tactile language capable of creating visual sensations essential to humanise the built landscape (Félix, 2013; Lefteri, 2003; Umbelino, 2013). 


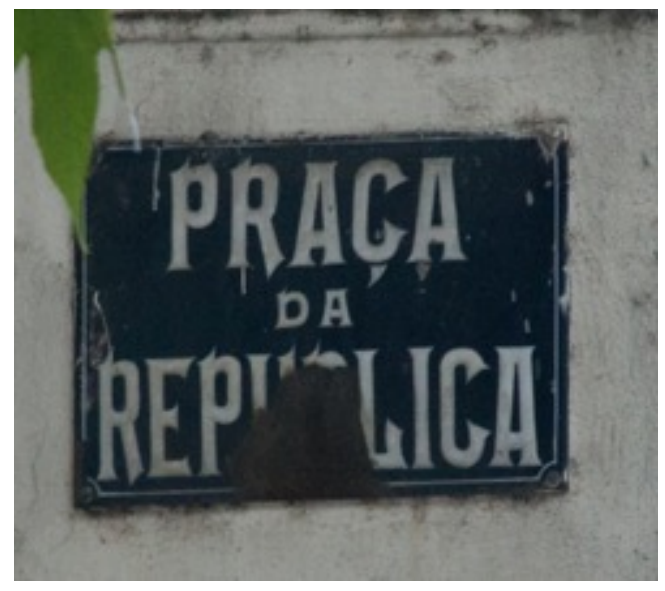

Figure 3. Coimbra Toponym Signage on a brass plate. Source: () Santos, (2014).

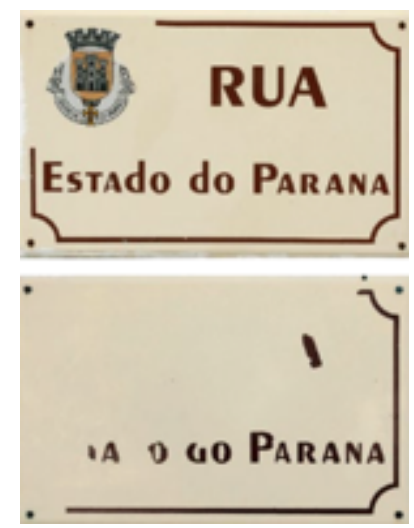

Figure 4. Castelo Branco Toponym PVC signage with information disposed on trimmed vinyl applied on top.

Source: Félix, (2013: 24).

Typography's presence on toponym signage is a piece of evidence that it surpassed the paper printing boundaries coming automatically, ubiquitous and inevitably, into our everyday visual universe on an intangible form (Jury, 2007).

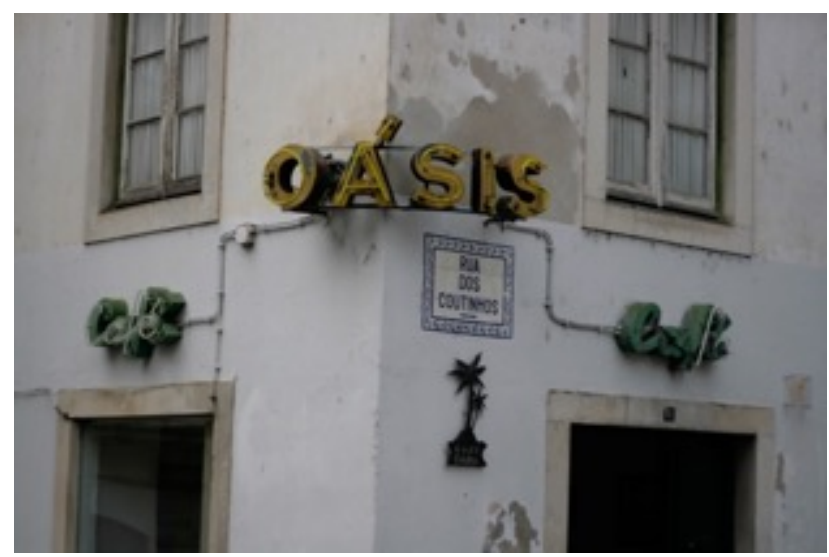

Figure 5. Overall appearance of Café Oasis' letterings at Sé Velha Square, Coimbra. Source: () Santos, (2014). 
During the research,

THEREHAS BEENACERTAIN AMOUNT OF CARE ANDATTENTIONWHLEREGISTERING

\section{THE SURROUNDINGS OF EACH SIGN.}

as well as other widely availab le typographic assets.

During the research, there has been a certain amount of care and attention while registering the surroundings of each sign, as well as other widely available typographic assets. Warnings, posters, advertisings are also a part of each place's identity, so it is possible to interpret that information as an open-air museum, or a museum of the every day, which is bringing a radical transformation of the function of art (Reis, 2012), because if typography makes any sense, it is visual and historical (Bringhurst, 2004). In the course of history, typography has always been an activity at culture and written communication's service (Balius, 2013).

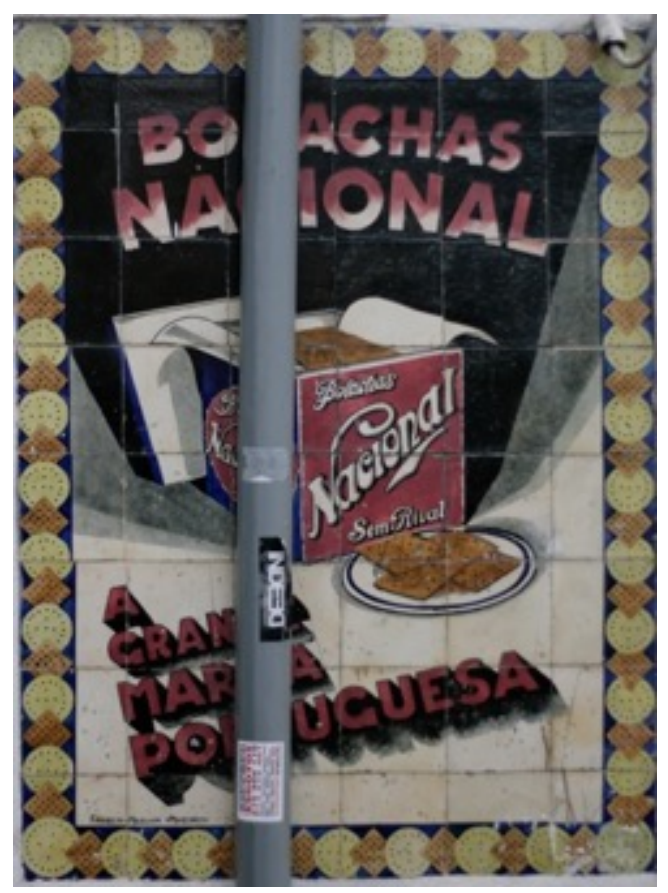

Figure 6. Nacional cookies' advertising on Ceramic Tiles, Coimbra.

Source: $\odot$ Santos, (2014).

The diversity of typographic families urges the need to classification it. The forms of letters are not exclusively scientific objects, they are also a part of art and history, as well as a part of disciplines like music, painting or architecture (Bringhurst, 2004). The history of typography should be understood as the relation between the several styles and the history of mankind from a political, philosophical and artistic point-ofview (Bringhurst, 2004). Adrian Frutiger (cited in Ruder, 2009) adds that typography is a record of the cultural heritage of every epoch. Emile Ruderalso states that typography has an active and functional role in the history of communication and mankind (2009).

The form of typography depends on the language of each script and its materiality, and refers to a spatial perception of what surrounds each, contributing directly to the construction of space in memory (Umbelino, 
2013). In Sebastião Rodrigues' opinion (cited in Fior, 2005), design is a discipline capable of communicate a spatial, or rational, expression of the men's world, constructed by its knowledge, imagination, desires and will. Typography as a vivifying element of communication has a tremendous identity capacity, essential to activities like branding (Afonso, 2014).

The objective of good typographical practice is form subordinated to legibility (Ruder, 2009). This is complemented by intangible aspects like energy or fluidity, which lead to serenity, spontaneity, witticism or taking pleasure in reading (Bringhurst, 2004). Every interpretation depends on the individual constructs of every reader, which is essential in the understanding of messages (Mitchell, 2005).

The form of typography has evolved during history. It is an activity at culture and written communication' service (Balius, 2013; Ruder, 2009). The proliferation of printing technology made a greater information and knowledge dissemination possible, together with the development of new typographic forms. It was in the 15th century, with the Roman do Roi's commission by the king Louis XIV, when the royal French written communication style was standardised (Meggs, 2006) starting the typographic neoclassic period (Bringhurst, 2004) where letter forms take a geometric and rational aspect (Meggs, 2006).

In Portugal, responding to the Roman du Roi movement, John V, created the Royal Academy of Portuguese History, to preserve the history of the Portuguese Empire. In the process, he acquired the equipment, punches, vignettes and types. Artists from Northern Europe, France and the Dutch Republic were hired to master the art of printing, beginning the type foundries in the kingdoms. At that time, Dutch typography stood out because of its formal qualities (Dias, 2012). Type creation and foundry in Portugal is owed to Jean de Villeneuve, a type founder for the King of France, who developed new types in several styles. $\mathrm{He}$ was called in 1763 to coordinate the King's Letter Factory, where he collected the punches created through his entire career, culminating in an extremely important event for the history of the Portuguese typography. Villeneuve's typography characterises as a transactional style (Dias, 2012), which did not follow the Roman du Roi tendencies, where proportion and rationality ruled (Dias, 2012). The former also helped to create the first metric system for typefaces (Meggs, 2006; Dias, 2012).

One of the first type classification systems appeared in 1900 by the hand of Theodor Law de Vinne, an American printer, who developed a complex and unspecific system (Di Pietro, 1999; Dixon, 1995). Francis Thibaudeau was the first to conceive a type classification system based on serifs kind while elaborating the Renault \& Marcou e Peignot \& Cie. Foundry typographic catalogues (Loubet del Bayle, 2012). In the " 50's Maximillien Vox deepened the typographic families' classification by the formal aspects of characters and the history of typography. In 1962 the International Typography Association (ATyPI) adopted the Vox classification, which was known since then as Vox-ATyPI (Stock -Allen, 2011). This system was then adopted in Germany, DIN 16518 ( Childer et al., 2013), and in Great Britain, British Standards 
2961 (British Standards , 1967 ; Baines \& Haslam , 2005). In 2010, ATyPI started a workgroup to update its type classi fication system (ATyPI ,2013). Despite VOX-ATyPI being the most commonly accepted typographic classifi cation system in the universe of type enthusiasts (Reis, 2008), some authors have developed other classification systems, updating and complementing this system according to their historicist logic(Bringhurst, 2004).

Despite the common acceptance of VOX-ATyPI, there is no consensus, as at least 25 other type classification systems exist (Childers et al., 2013). Robert Bringhurst states that despite the existence of numerous types of classification systems, all of them leave a lot to be desired (2004). However, it is so, as type classification and description is not only a science, but also a part of art and its history (Bringhurst, 2004 ). The history of typography should be understood as the relationship between artistic styles and the history of mankind, from a political, philosophical and artistic point of view (Bringhurst, 2004). It is also a record of the cultural heritage of each period (Ruder, 2009). František Storm (cited in Moura, 2008) defends that only knowing each language diacritics you will be able to use typography favouring content. Serifs are a formal element of a typeface and frequently are associated with a culture or region, on the other hand, non-serif fonts are considered neutral and international. This kind of geographical relationship is also argued by Bringhurst, who states that the text by a given author may be better composed by a typographic family of the same nationality , independent of what the design is or who the author is (2004). Profound knowledge of anatomy and the history of typography will facilitate the identification and classification of typefaces (Kane, 2002; Unos Tipos Duros, 2005).

Until 1974, Portugal was a very closed country, which was avoiding an early general visual homogenization of city centres (Baines \& Dixon, 2004). This allowed the existence of an unusual and inhomogeneous typographic heritage today. In the first half of the 20 th century, Portugal was culturally a very conservative country, resisting, for example, the introduction of the typographic mechanical composing over manual methods until the end of the '20's (Fior, 2005). This enabled the homogenizing of type families used. The rivalry between the north and the south may have contributed to the existent typographic diversity, due to the different economic activities of these regions. Up in the north, economic activities were more related to the exportation of textiles, agriculture and fishery, while in the south it was closer to the local commerce and diplomatic activities. Heterogeneity dictated that different commercial contacts were made by various types of foundries and printers across the country, leading to the situation in which different typographic measures and styles were adopted (Fior, 2005). This research arises around the study of typography and its diversity constructed throughout the ages in the Portuguese urban and toponymy signage. Its research objects are type families which withstood the homogenization imposed in the last quarter of the 20 th century, when multinational corporations began the signage and setting up urban furniture (Baines \& Dixon, 2004). 
These old letterforms absorbed the atmosphere and the historic moments in which they were born, becoming symbols of the space where - several generations lived and travelled through (Poynor, 2012; Baines \& Dixon, 2003). The urban signage standardisation on regional, or national scales promotes the loss of a place's identity and makes landscapes/cityscapes monotonous (Baines \& Dixon, 2003).

This study will enable building a digital archive which, according to Ernst (2013), through the medium's archaeological approach will make it possible to understand the epistemological implications of typography, and the mediums on which it operates (D'Encarnação, 2010). Where signal's processing, storage and transmission makes them active agents during knowledge production. The same author reiterates that these media events prove themselves essential to the general temporal cultural comprehension.

It is expected that this research will allow knowledge transfer from the specialist to the public domain. According to Balius (2013), the reflection on the social impact of typography is a field of study which needs further investigation.

\section{RESULTS AND DISCUSSION}

As previously presented, Portugal has a great diversity of its older toponymy signage, conferring a proper identity to each place's landscape.

\section{The oldest toponymy of this city has several}

\section{SHAPES, FORMS, AN D MATERIAL SUPPORTS,}

In this article, Coimbra's toponymy, its shape and identity will be approached. The city's contemporary toponymy signage has been defined by the city council. Traditional Portuguese ceramic tiles were chosen and described as an ornamental and utilitarian piece and the result of the process of an artisanal activity, which remounts to the long pottery tradition of the city (Nunes, 2008). In all the places where it is not possible to stick signage on a wall, it should be placed on a Stone of Ançã pillar, which also characterises this region. This way it does not create any conflicts with the aesthetics of new constructions (Nunes, 2008). The main goal of the Coimbra's toponymy commission is to preserve the memory of traditional and natural places, costumes, happenings, institutions, people or other reasons, things or objects that should be perceived as an example (Nunes, 2008). 


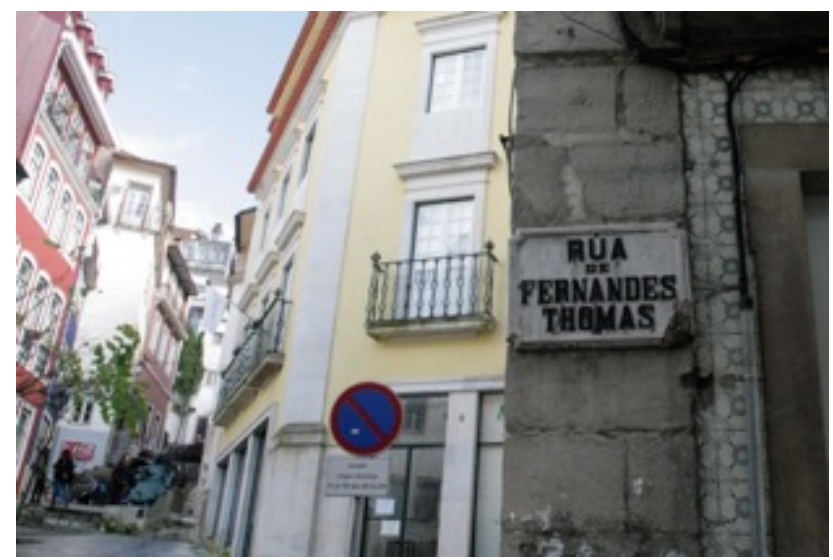

Figure 7. Fernandes de Tomas Street Signage, in Coimbra, and its involving space. An example of how toponymy signage can represent language evolution and date the identify space by its style. Source: () Santos, (2014).

The oldest toponymy of this city has several shapes, forms, and material supports, revealing to those who observe them, several stages or epochs this city has been through. Action research method made indicated us toponymy signage on marble, stone of Ançã, ceramic tiles, polymers and brass supports.

For the sake of simplification, we will present the samples ordered by the material support and then analysing their typographic nature and decoration motifs. The totality of the collected samples will not be shown, instead only the most interesting ones and toponymy with multiple signage will be displayed and analysed in-depth. The analysis of the samples is made by judging the formal aspects of typography and its material support conservation.

Stone of Ançã is a calcareous stone from the parish of Ançã , in the municipality of Cantanhede less than $15 \mathrm{~km}$ from the centre of Coimbra. The colour of this rock alternates between yellow and blue-white, and it is known for its malleability. For this reason, it was adopted in the gothic period for construction and sculpture, all over the Iberian Peninsula. It was not possible, until nowadays, to date with precision the application of this material, however, observing the typography, and the decorative motifs, it is possible to assume a long period of use, due to the variety of styles represented.

The author believes that the plates holding a mécane typeface will be the older city's toponymy representation, as this kind of typographic style appeared in the first half of the 19 th century. Th is process occurred simultaneously to the practice of naming streets, squares and places. The presence of art deco style, which was popular until the Second World War, is visible on this material support, either in the ornamentation or typography. 


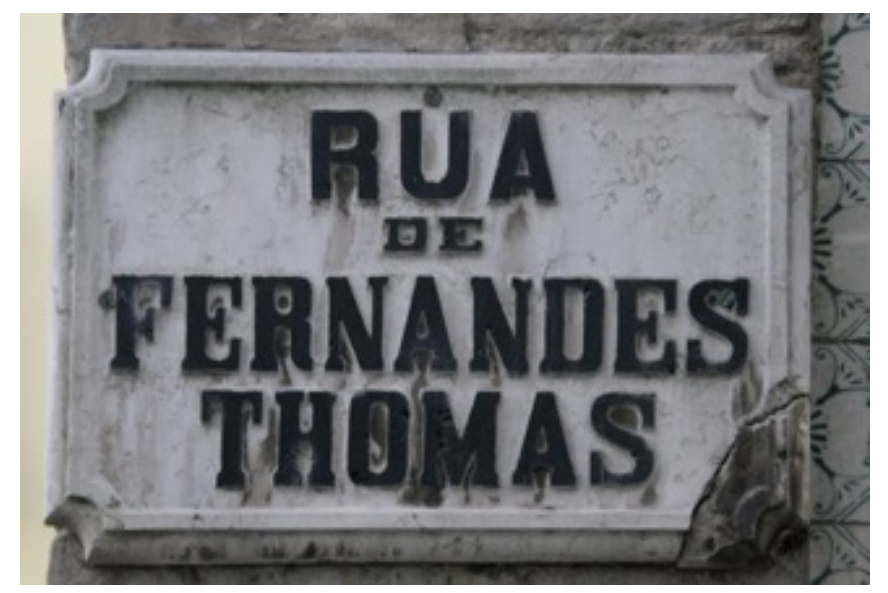

Figure 8. Fernandes de Tomás Street Signage, in Coimbra. Closer perspective on this mécane typeface on Stone of Ançã. Tomás is written in the old Portuguese.

Source: () Santos, (2014).

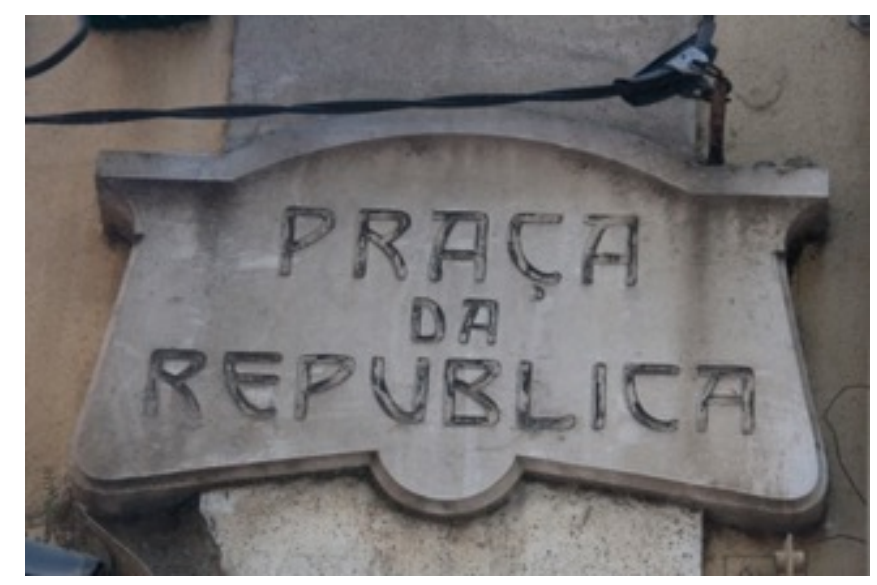

Figure 9. Praça da República Street Signage, in Coimbra.

One example of art deco in Coimbra's toponymy.

Source: () Santos, (2014).

Thomas, Commercio and Jacintho allow us to infer that this toponymy's date is earlier to the orthographic agreement of 1945 (ILTEC, n.d.). It allows us to familiarise ourselves with the older Portuguese spelling and its evolution.

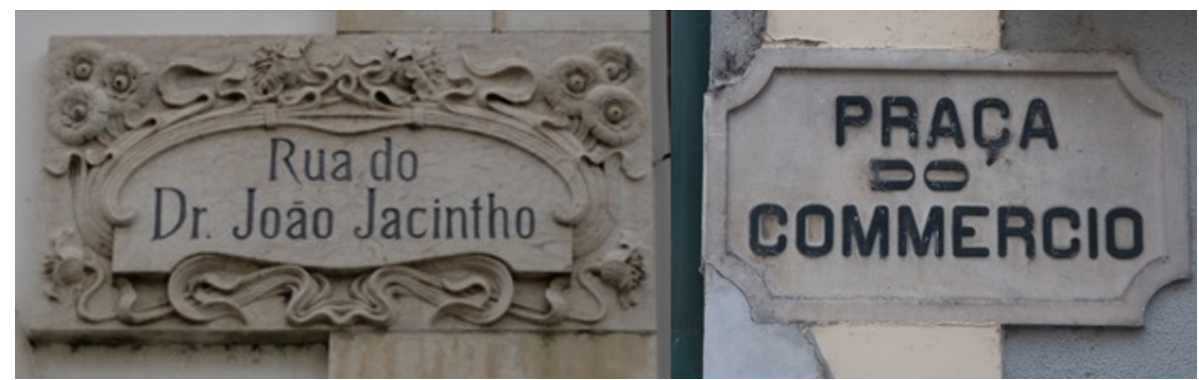

Figure 10,11. Jacintho and Commercio, old- Portuguese spelling present on the streets of Coimbra. Source: photograph of the author, (2014). 


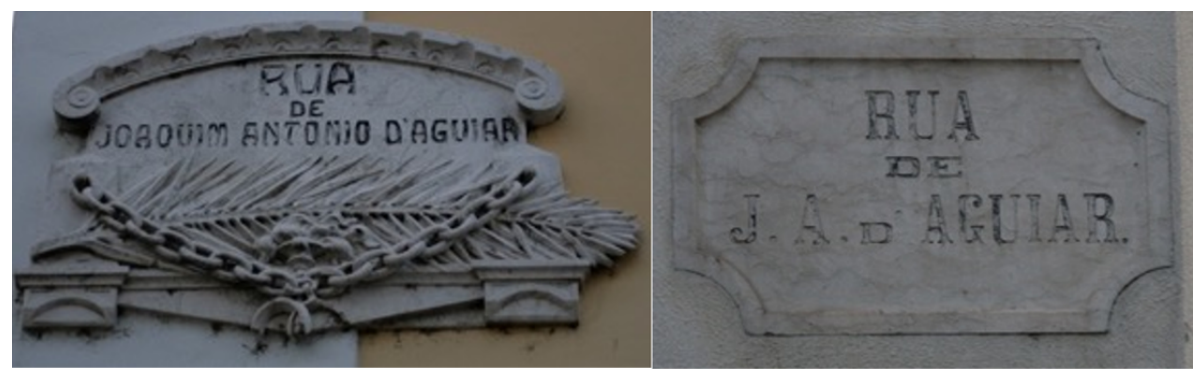

Figure 12, 13. Joaquim António D’Aguiar Street Signage. The first example is possibly from the 1 st half of the 20th century, using the elements of the art deco style and a typeface similar to Hobo. The second plate has a mécane typeface like Fernandes Tomás Street, which refers back to the 19th century.

Source: Photograph of the author, (2014).

From all the samples made in Stone of Ançã only José António Aguiar Street has more than one signage, presuming that the simpler one is the older one, judging from the level of erosion Typefaces coincidence suggests the hypothesis that the original city toponymy signage used a mécane typeface.

Coimbra's toponymy signage decoration is abundantly visible on plates where Humanist and Transitional typefaces were applied, yet Capitão Luís Gonzaga (military on service during WWI) street signage decoration is far more complex than the other examples exhibiting the Portuguese Republic symbols and the distinction of the Order of the Tower and Sword. This is a rare example, unique in the city of Coimbra, where signage indicates the role and importance of the honoured person.

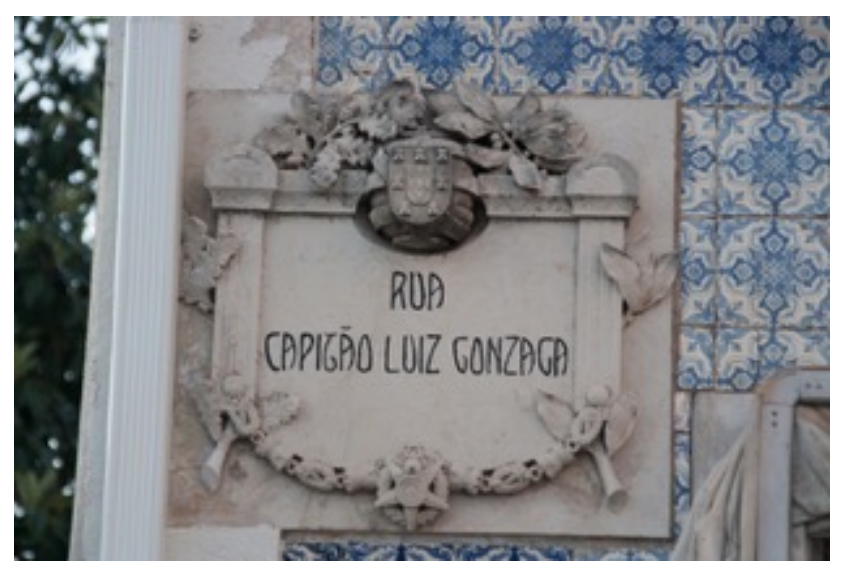

Figure 14. Capitão Luís Gonzaga street has a Second Republic decorative style honouring this World War I national hero.

Source: ( Santos, (2014).

Toponymy signage made in marble is rare in Coimbra. Their arrangement through the streets of Coimbra is sparse. There are only two dark marble plates which are very close to each other at Santo António dos Olivais zone, which is mostly known for its church which was a part of the former Monastery of Celas. This zone was a city suburb until the '20s. The Marble toponymy plates display different typographic forms, with a predominance of the transitional fonts towards the others. 
The plates on this material are usually not decorated, with the exception found in figure 18, with simple forms fixed with iron nails in each corner.

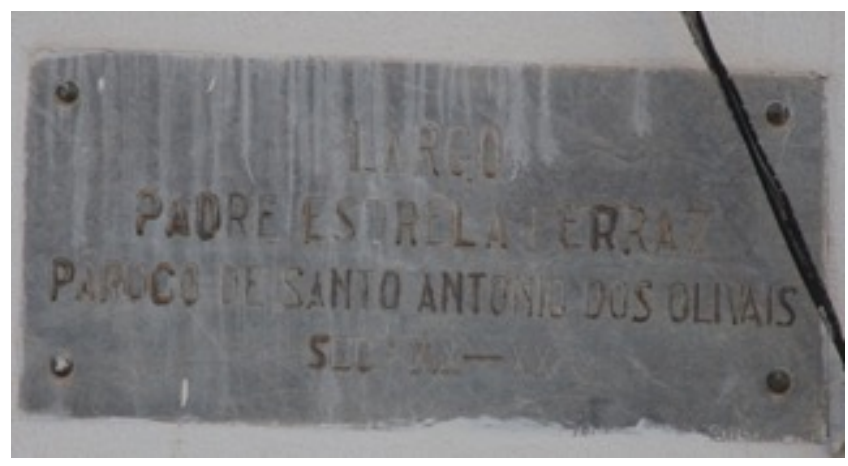

Figure 15. Dark marble toponymy signage. One of the two specimens. Source: $\odot$ Santos, (2014).

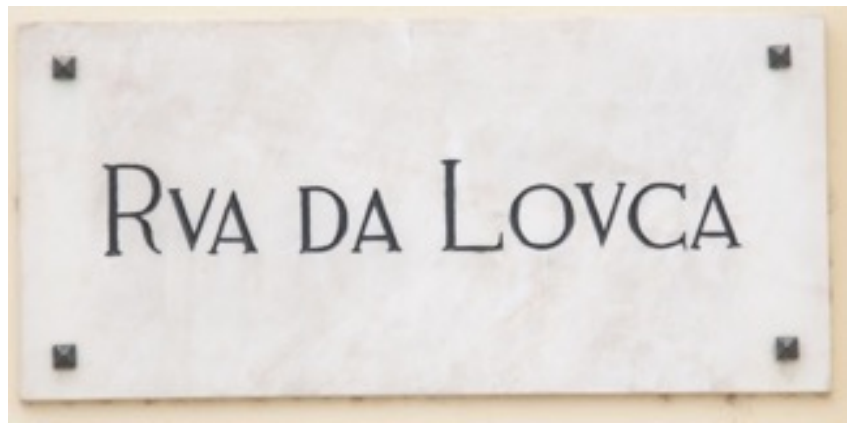

Figure 16. Another marble toponymy signage with a transitional typeface. Source: CSantos, (2015).

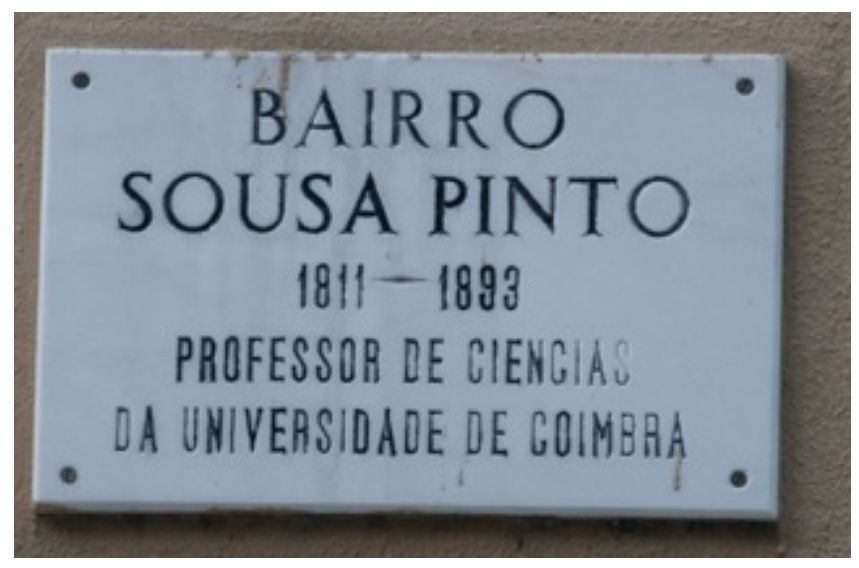

Figure 17. A different transitional typeface combined with a narrow grotesque typeface on a marble plate.

Source: () Santos, (2015). 


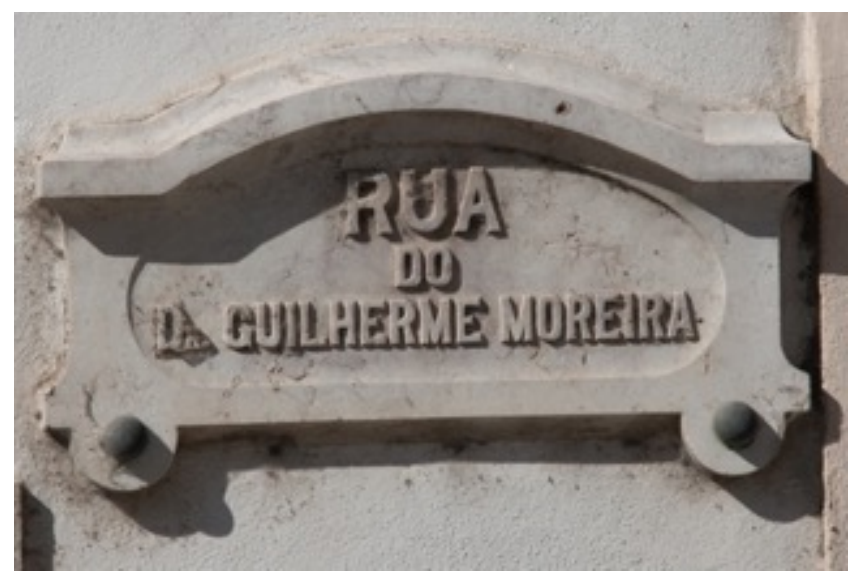

Figure 18. Decorated marble plate with a modern lineal neo-grotesque typeface.

Source: $\odot$ Santos, (2015).

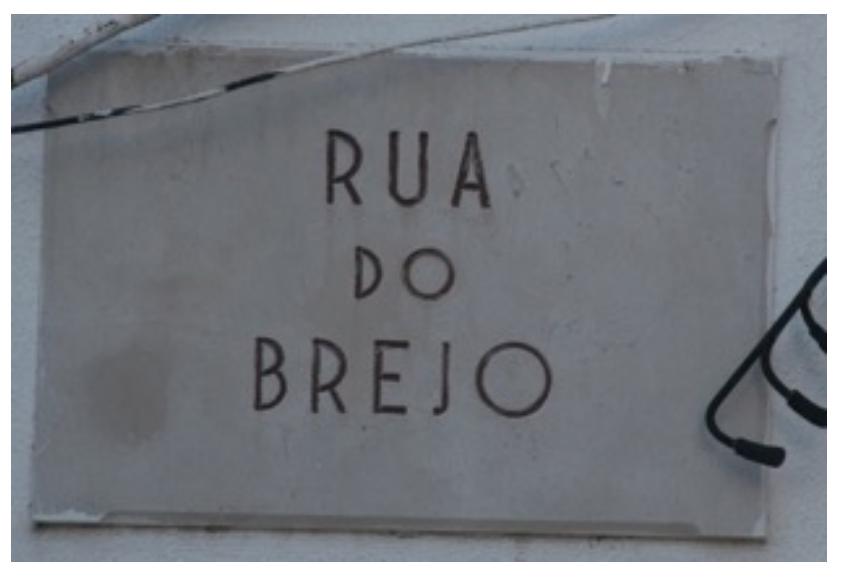

Figure 19. A rare specimen using a geometric typeface Source: (๑) Santos, (2015).

Toponymy signage on metallic supports is even more scarce in Coimbra. During this research, we have only found one plate using this material in the city streets (figure 3). However, we have found another two plates inside the Pra-Kis-Tão students' republic house which we could not confirm, until today, if they were indeed from the old streets of Coimbra.

This material is popular in Coimbra, indicating door numbers. 


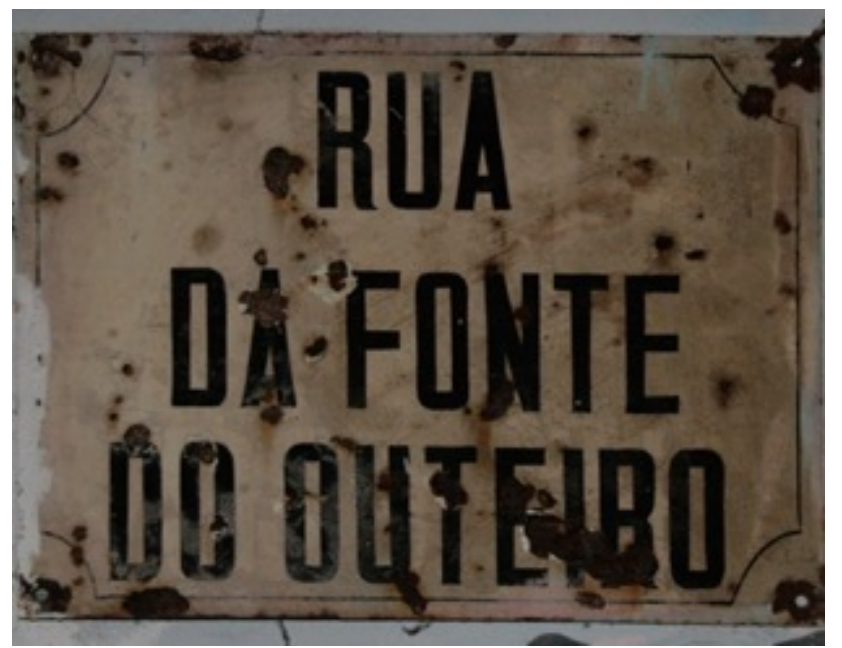

Figure 20. An old brass toponymy sign was found inside Pra-Kis-

Tão students republic while using action-research methodology. Source: (C) Santos, (2014).

There is in great number toponymy signage made of polymers like PVC, especially in downtown and the São Sebastião sidewalk, near St. António dos Olivais, Unlike Castelo Branco's example (figure 4) every sign was well conserved and readable, yet with poor legibility. We presume that these plates are prior to 2004 , when the Coimbra's toponymy city council established ceramic tiles as its official material (Nunes, 2008).

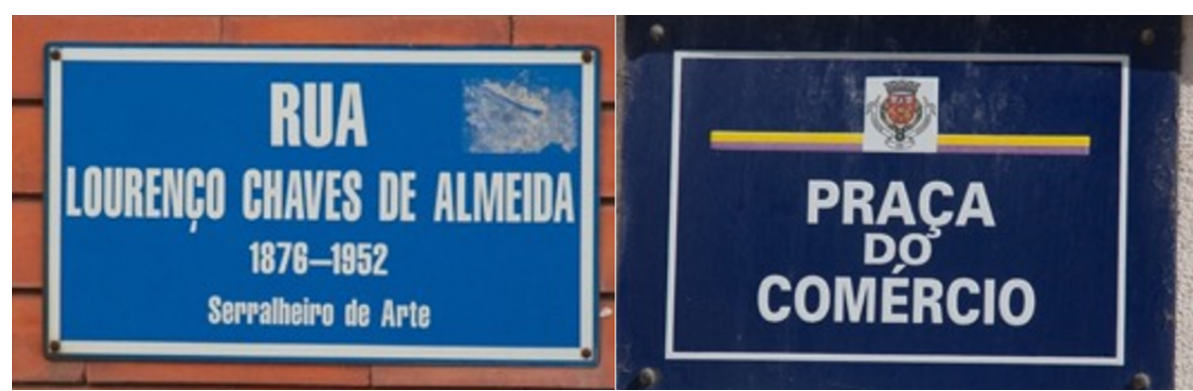

Figure 21, 22. Different PVC signage in Coimbra. The first plate is located at the São Sebastião sidewalk, while the second one is in the downtown.

Source: () Santos, (2015).

Ceramic is the most popular material in the city's toponymy signage. It is on ceramic tiles that we find most ornamentation and typographic diversity. Judging from the broad scope of styles and location disparity. We can assume that "Largo da Feira dos Estudantes" and "Calçada Martim de Freitas" are contemporary as they have similar art and are found in the evolving area of the old castle of Coimbra which was intervened from 1942 until 1970. 


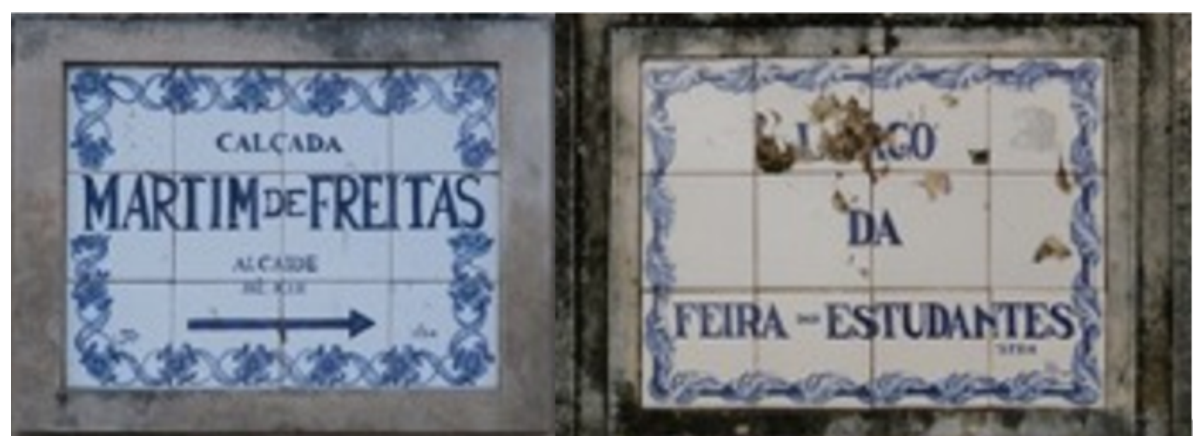

Figure 23, 24. "Calçada Martim de Freitas" and

"Largo da Feira dos Estudantes" ceramic tiles signage. Source: $\odot$ Santos, (2015).

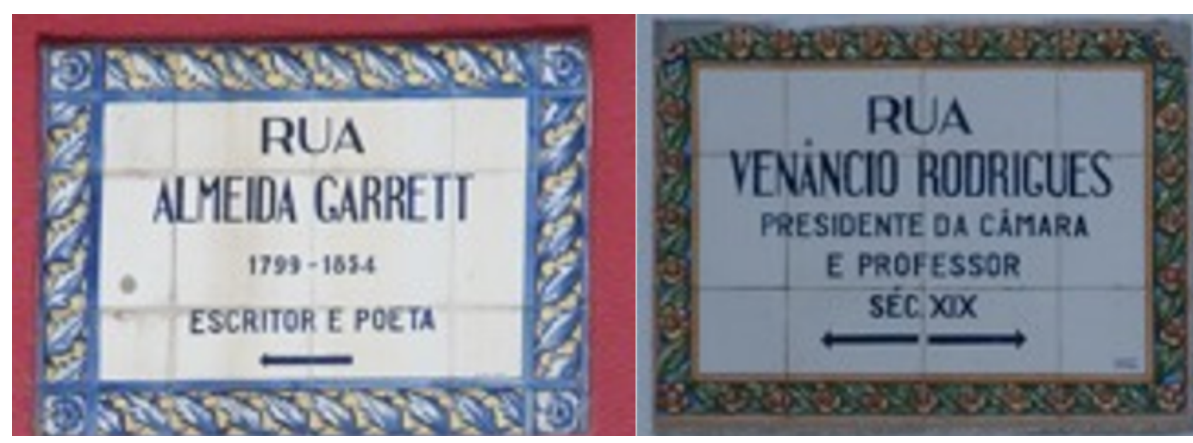

Figure 25, 26. "Venâncio Rodrigues" and "Almeida Garret" streets' toponymy signs have the same typography and similar ornamentation shapes.

Source: () Santos, (2015).

It is on ceramic tiles that we will find more typographic diversity but also a stronger design unity trough the several historic stages of this city. For example, "Venâncio Rodrigues" and "Almeida Garret" streets' signs share the same typographic family and information hierarchy with similar ornamental shapes.

Letter signs like "Travessa da Rua Velha", in the downtown, or "Beco de S. Cristovão", in the old town, support the hypothesis that ceramics have been used before 1942 .

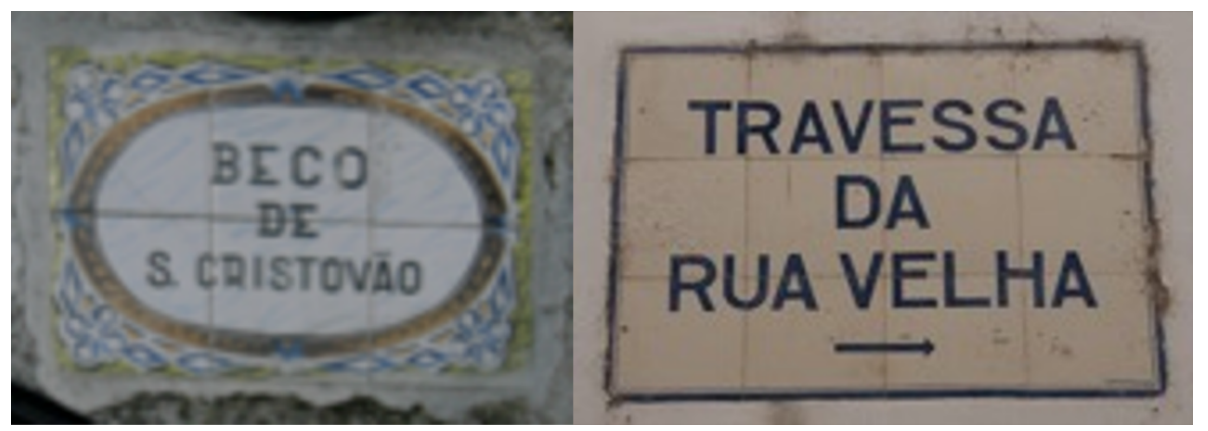

Figure 27, 28. "Travessa da Rua Velha" and "Beco de S. Cristovão" toponymy plates are located in the zones of Coimbra which did not suffer from any intervention during the Second Portuguese Republic.

Source: () Santos, (2014). 


\section{CONCLUSIONS}

Coimbra is a big campus town with a vast area and heritage recently classified as the UNESCO World Heritage. Opposite to Évora, it is still unknown how the city's toponymy will be managed from now on. The city's toponymy signage uses a vast number of materials and artistic styles, to guide people within the city of Coimbra. This diversity will help whoever knows the city to identify in which zone he is in, by its design. Most signages use uppercases, but there are some rare mixed case specimens. Those mixed-case signals have a better legibly due to higher letter shape contrast (Terminal Design, 2004).

Until the present moment it is not possible to obtain more information about the city's toponymy, but we can state that we are facing a very fragmented system, which nevertheless allows the passer-by to get to know a little more about the city, by the called names and places, the language, through the old and contemporary spelling, and even by typography itself.

Portuguese toponymy styles differ from city to city and between epochs, being an indirect glance to the local societies. For such further studies, are necessary beyond the scope of design, to understand the aesthetics and toponymy choices made in each place.

\section{Typogrophy has way mone power than \\ A SIMPLE COMMUNICATION MEDIATOR \\ has $\dot{a}$ absorbs and reflecis \\ THE SPIRIT OF ITS OWN TIME.}

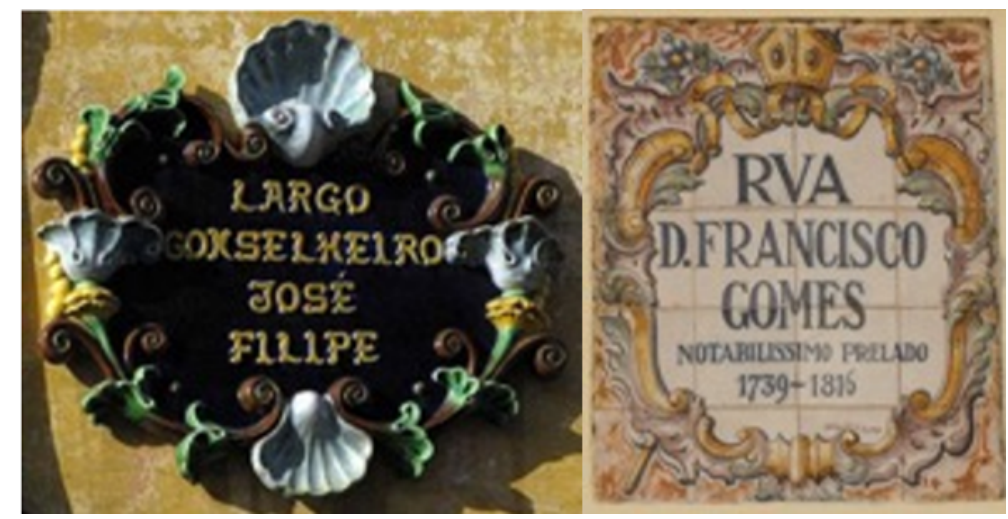

Figure 29, 30. Portuguese Toponymy in Faro (CSantos, 2014) and Caldas da Rainha. Source: (C) C.M. Caldas da Rainha, (2013).

This research is still in its initial stage, but it already shows us that investigating toponymy and typography, it is possible to identify each place's micro-identities, revealing not only their local and national history, but also the predominant aesthetics and linguistic of each period.

Approaching typography as an element of a place's artistic identity is recognising that it has the power of demarking a particular hallmark of something on which time is the main responsible for its prevalence 
until today (Afonso, 2014). Typography has way more power than a simple communication mediator has it absorbs and reflects the spirit of its own time. This spirit is preserved and activated as it the text is read and the reader is confronted to either the elements of the past, that toponomy honours, and the artistic options present on the materiality of toponymic signage. This is a research that goes further the scope of design, but uses it as a relationship catalyser between typography, art, space, memory and presence. It is within these elements that it could be possible to understand how valuable is the honoured asset on toponomy and find a starting point to discover its history and how it influenced our present. By this means, this project turns (Twemlow, 2004) bringing together disciplines and perspectives in an unusual relationship.

This research aims to identify, learn about and preserve typefaces found on the squares and streets of Portugal, allowing the universal fruition of this heritage through its documentation and display in an open digital archive. This kind of archive would allow not only to make the research publicly available, but it will also allow other enthusiasts to help and contribute.

\section{REFERENCES}

Afonso, H. (2014), Letreiros toponímicos do centro histórico eborense. (J. dos Reis, Ed.). Évora, Portugal.

Arthur, P. \& Passini, R. (1992), Wayfinding: people, signs, and architecture, Focus Strategic Communications Incorporated, Oakville.

ATypI (2013), ATypl. [online] Available at: http://www.atypi.org/, accessed 25 Apr 2012.

Baines, P. \& Dizon, C. (2003), Signs: lettering in the environment, Laurence King, London.

Baines, P. \& Dizon, C. (2004), Letter rich Lisbon. Eye 54 [online] Available at http://www.eyemagazine.com/feature/article/letter-richlisbon-extract, accessed 18 May 2014.

Baines, P. \& Haslam, A. (2005), Type and Typography, Laurence King.

Balius, A. (2013), The Value of Typography in a Global MultilingualWorld. Temes de Disseny, Ed. ELISAVA Escola Superior de Disseny.

Barreto, L. (2005), Wayfinding em aeroportos: tipografia aplicada nos seus sistemas de sinalização. MsC, Universidade Técnica de Lisboa, Faculdade de Arquitectura: Lisbon, Portugal .

Berger, A. A. (1995), Essentials of Mass Communication Theory, SAGE Publications.

British S. (1967), Typeface Nomenclature and Classification, British Standards Institution.

Bringhurst, R. (2004), The Elements of Typographic Style, Hartley \& Marks, Publishers.

Childers, T., Jessica, G. and Liberty L. (2013), 25 Systems for Classifying Typography: a Study in Naming Frequency. Parsons Journal for Information Mapping. 
D’Encarnação, J. (2010), “A Toponímia, Fonte Histórica Também Para a República”, Biblios, vol.6, núm. 2. pp. 73-81.

Di Pietro, Anthony Kllc (1999), A Database of Typeface Classification Systems. Thesis. Rochester Institute of Technology, NewYork.

Dias, R. (2012), A letra de imprensa na Academia Real da História Portuguesa na primeira metade do século XVIII. $3^{\circ}$ Encontro de Tipografia. pp. 102-115.

Dixon, C. (1995), Why we need to reclassify type. Eye, 19. pp. 86-87.

Ernst, W. (ed.) (2013), "Digital Memory and the Archive". En Minneapolis, University of Minnesota Press, London, pp. 1-277.

Fior, R. (2005), Sebastião and the Development of Modern Graphic Design in Portugal. PhD. University of Reading: Uk.

Félix, A. (2013), Uma modularidade tipográfica na azulejaria da placa toponímica. (L. Arruda \& R. R. Dias, Eds.). MsC. University of Lisbon, Faculty of Architecture: Lisbon, Portugal.

Jury, D. (2007), O que é a tipogra fia. GG. Barcelona .[En línea] https:// www.amazon.com.br/Que-É-Tipografia-David-Jury/dp/8425221447, consultado el 18 de noviembre de 2018.

Houaiss, A., Villar, M.S. (2001), Dicionário Houaiss da língua portuguesa, I-VI. Círculo de Leitores, Lisboa.

Kane, J. A. (2002), Type Primer, Laurence King, London, UK.

Lefteri, C. (2003), Ceramics: Materials for Inspirational Design, RotoVision.

Loubet del Bayle, J. (2012), Des caractéres typographiques et de l'art et de la science des letters que l'on dit romaines. [online] available at http:// caracteres.typographie.org/classification.html, accessed 2 November 2012.

Meggs, P. B. \& Purvis, A. W. (2006), Meggs' History of Graphic Design. (John Wiley Sons, Inc., Ed.) (4 ed.). Hoboken, New Jersey: John Wiley \& Sons.

Mitchell, W.J. T. (2005), There Are No Visual Media, Journal of Visual Culture, vol. 4, núm. 2, pp. 257-266.

Moura, M. (2008), Acentos. The Ressabiador. [online] Available at http:// ressabiator.wordpress.com/2008/06/05/acentos/, accessed 20 de junio 2013.

Nunes, M. (2008), Novos Topónimos - Coimbra (2002-2008), Departamento de Cultura - Divisão de Acção Cultural, Coimbra.

Poynor, R. (2012), Typographic Stories of the City Streets. Available at www.observersroom.designobserver.com/rickpoynor/post/ typographic-stories-of-the-city-streets/33078/, accessed 3 May 2013.

Reis, J. (2012). Três movimentos da Letra: o desenho da escrita em Portugal. Terceira parte, Expressão e Conceptualçãizao da Letra. Biblioteca Nacional de Portugal. Lisboa.

Reis, Jorge dos (2008-12-17). Classificação Estilística: Na Senda de Um Paradigma Tipográfico. Available at: http://convergencias.esart.ipcb.pt/ artigo/35 at 2014-03-15, accessed 20 de junio 2013.

Reminghton, R. (2012), Reputations: Massimo Vignelli. Eye, (83). pp. 12-26.

Ruder, E. (2009), Typographie: Ein Gestaltungslehrbuch. (8th ed.). Sulgen, Switzerland: Verlag Niggli AG.

Stock-Allen, N. (2011), A Short Introduction to Graphic Design History - Methods of Type Classification. 
Available at: http://www.designhistory.org/Type_milestones_pages/ TypeClassifications.html., accessed 20 de junio 2013.

Terminal Design, Inc. (2004), ClearviewHwy. Available at http:// clearviewhwy.com/ at 2017, 5 th of November.

Twemlow, A. (2004), Forensic Types. Eye (54). Available at: http:// www.eyemagazine.com/feature/article/forensic-types at 2014-05-20, accessed 22 de junio 2018.

Uebele, A. (2007), Signage systems \& information graphics: a professional sourcebook, Thames \& Hudson, Nova Iorque.

Umbelino, L. (2013), Espaço Fantasma, Colégio das Artes da Universidade de Coimbra, Coimbra. 